\title{
Redefining the Role of Religion in Contemporary Society: Pope Francis and Sheikh Ahmad Muhammad al-Tayyeb
}

\author{
Heri Setyawan ${ }^{1 *}$ \\ ${ }^{1}$ Universitas Sanata Dharma Yogyakarta - Indonesia
}

\begin{abstract}
This paper discusses the position of religion in contemporary society by examining the religious thoughts of two prominent religious leaders: Pope Francis from the Catholic Church and Sheikh Ahmad Muhammad al-Tayyeb from Al-Azhar University, Egypt. The meeting between Pope Francis and Sheikh Ahmad Muhammad al-Tayyeb in Abu Dhabi (February 2019) is a starting point for understanding the process by which the two religious leaders redefined the role of religion in society. Moreover, their responses to contemporary social issues such as terrorism, ecological crisis, war, and social injustices also show how they redefined the role of religion. While each religious leader formulates theological account into its religious tradition, it is obvious that the role of religion for social transformation and humanity is shown to be the central concern of the two religious' leaders. The two religious traditions go further to put religion as a fundamental agent for society transformation.
\end{abstract}

Artikel ini membahas posisi agama-agama dalam masyarakat kontemporer dengan memeriksa pemikiran keagamaan dua pemimpin agama terkemuka: Paus Francis dari Gereja Katolik dan Syekh Ahmad Muhammad al-Tayyeb dari Universitas Al-Azhar, Mesir. Pertemuan antara Paus Fransiskus dan Syekh Ahmad Muhammad al-Tayyeb di Abu Dhabi (Februari 2019) merupakan titik awal untuk memahami proses di mana kedua pemimpin agama mendefinisikan kembali peran agama dalam masyarakat. Selain itu, respons mereka terhadap masalah sosial kontemporer seperti terorisme, krisis ekologi, perang, dan pencarian keadilan juga menunjukkan bagaimana mereka mendefinisikan kembali peran agama. Sementara masing-masing pemimpin agama tersebut merumuskan kisah teologis ke dalam tradisi keagamaannya, jelaslah bahwa peran agama untuk pembaruan masyarakat dan kemanusiaan ditunjukkan sebagai pusat dari kedua pemimpin agama itu. Kedua tradisi agama melangkah lebih jauh untuk menempatkan agama sebagai agen mendasar untuk pembaruan masyarakat.

Keywords: Pope Francis; Sheikh Ahmad Muhammad al-Tayyeb; social issues; fraternity; religion

*Corresponding Author: Heri Setyawan (hherisetya@usd.ac.id). Universitas Sanata Dharma, Jl. Affandi, Mrican, Caturtunggal, Depok, Sleman, Yogyakarta, Indonesia 55281. 


\section{Introduction}

The meeting of two prominent religious leaders, Pope Francis and Sheikh Ahmad Muhammad al-Tayyeb, in Abu Dhabi February 2019, gave a new perspective not only on interreligious dialogue but also on the role of religion in contemporary society. The two leaders agreed on the importance of the role of religion in dealing with contemporary social issues. The meeting and the signed documents "Human Fraternity" become an oasis of the role of religion amid religious conservatism and the danger of terrorism in the name of religion. Furthermore, it was obvious that different religions can collaborate and work together for solving social problems.

The commitment of Pope Francis and Sheikh Ahmad Muhammad al-Tayyeb as indicated in The Document on Human Fraternity for World Peace and Living Together" is based on the profound religious thoughts of the two leaders that religion must work together in promoting peace and justice, countering violent religious extremism, conserving environment, eradicating poverty and many other issues. These prophetic concerns could be understood from their talks, speeches, and documents.

A study on the role of religion in contemporary society had been done by several scholars. Some of them were done by José Casanova (2009) and Nancy T. Ammerman (2014). Casanova (2009) revisits the argument first presented in Public Religions in the Modern World (1994) to ascertain the extent to which the theoretical-analytical framework developed. By applying literature review and reflection, this study concludes that the dynamics of religion, politics, and gender equality are unavoidable due to the global imperative to develop comparative analytical frameworks which are applicable beyond Western Christian contexts and the challenges to place the politics of gender equality and the related religious-secular debates in the public discussion on religion. This study is in line with the research of Albie Sachs (2012) in his "Liberty, Equality, Fraternity: Bringing Human Solidarity Back Into the Rights Equation". Sachs states that the equity rights should be refound especially in the mid of global wave of religion in public life.

Ammerman (2014) has another focus of study. Based on the research about "lived religion", in her "Spiritual Narrative in Everyday Life", she states that religion may be found in conversational spaces -both in religious organizations and beyond- where the dimensions of the sacred and mundane are produced and negotiated. In this context, the religious phenomena may be found in everyday life in various forms and styles by following the social context in which the phenomena exist.

Therefore, this writing aims to explore the religious thoughts of Pope Francis and Sheikh Ahmad Muhammad al-Tayyeb on the role of religion in facing contemporary social issues. This study applies the public sphere theory from Jürgen Habermas, specifically on the relation between religion, secularization, and post-secularization (Habermas 2006). Habermas argues that religions in secular society become a source of morality which give moral supports for its adherences. Religions provide values that order their followers to doing good for society. In other words, secularization and religion are interdependence. Religions give moral supports for the secular society, at the same time, secularization provides a 
space for religion to grow in public (Habermas 2001, 2008).

The writer examines the speeches, talks, and documents which were published by Pope Francis and Sheikh Ahmad Muhammad al-Tayyeb. Considering question about the religious thought of Pope Francis and Sheikh Ahmad Muhammad al-Tayyeb in responding to social problems, this paper argues that religion is an important agent to promote world peace and the common good. World peace and common good become an arena for religions to coexist and work together. Although the two leaders explore theological values of their respective religions, both agree that working for world peace and the common good is a fundamental task of every religion. Exploring their views would give a fresh approach to the role of religion in contemporary society.

The writer firstly provides a brief biography of the two religious leaders: Pope Francis and Sheikh Ahmad Muhammad al-Tayyeb, particularly on their religious leadership. Secondly, the writer discusses the two leaders' views and responses to contemporary social issues. Thirdly, the writer synthesizes the role of religion in dealing with social problems. By showing these topics, the redefinition of the religion of these two religious leaders could be understood. Furthermore, it contributes to the discourse of religion and society which nowadays becomes a serious issue in the public sphere.

\section{Biography of the Both Leaders}

\section{Pope Francis}

The conclave or the pope election in 2013, after the resignation of Pope Benedict XVI, brought a surprise to the Catholic Church and the world. The conclave appointed Cardinal Jorge Maria Bergoglio, SJ to be the 266th pope. It was surprising because the name Bergoglio in many ways was unpredicted. He is from Latin America, the Archbishop of Buenos Aires, and a nonEuropean. Bergoglio is an Italian descendent who migrated to Latin America in 1929. He grew up in Buenos Aires. Bergoglio is also a Jesuit, one of the orders in the Catholic Church, and his appointment makes him the first Jesuit pope in the Catholic Church history. Before the conclave, Bergoglio was also not a central figure in the Catholic curia in Rome, different from several Cardinals who were working in Rome in the circle of Pope Benedict XVI.

After being elected as a new pope, Bergoglio is known for being still humble, modest, and having a simple lifestyle as he is known before in Buenos Aires. He chose a pontifical name Francis so that since that time, he is known as Pope Francis. The name Francis is originally taken from Francis of Assisi, a Catholic saint from the 12-13 Century who was known for his simplicity of life and his work for peace. Bergoglio, as an Archbishop in Buenos Aires, also got admiration for his simplicity of life. Reforming his predecessor of lifestyle, as a bishop, he cooked his meals by himself, resided in a two-room apartment, and used public transportation to move around. Bergoglio is also known for his preferential to serve the poor (Kaiser 2014:3). Soon after being elected as a new pope, Pope Francis kept showing his simplicity of life. He did not move to the Apostolic Palace, rather he kept staying at the Casa Santa Marta where he and other cardinals were staying during the conclave. As a new pope, 
he was reported paying his bill himself for residing in Casa Santa Marta, taking meals together with other cardinals who were residing there, celebrating Mass in a small chapel in Casa Santa Marta, and still taking public transportation to transfer (Kaiser 2014:4,5).

Keeping the spirit of simplicity, in the first years of his leadership, the newly elected Pope has shown his concern in reforming the Catholic Church in terms of being a simple Church that works for the poor and plays its role in world peace. He chose his first trip outside Rome to visit Lampedusa on July 8, 2013, where thousands of illegal migrants tried to reach Europe, many of whom drowned in the sea. In Lampedusa, Pope Francis spoke about "globalization of indifference" where many people and nations kept silence despite seeing many migrants perished in the sea (Homily of Holy Father Francis: Visit to Lampedusa, 2013).

Pope Francis also visited several countries to do apostolic visits and to meet prominent leaders from around the world. Some of his visits are historical. In 2014, he visited Amman, Bethlehem, and Jerusalem, South Korea, Albania, Strasbourg France, Turkey. From 2015 to 2017, Pope Francis did many visitations to different continents. In 2015, Pope Francis visited Sri Lanka and the Philippines, Bosnia, Bolivia, Ecuador, Paraguay, Cuba, and the United States. He also visited Kenya, Uganda, and the Central African Republic. In 2016, Pope Francis visited Cuba and Mexico, Greece, Armenia, Poland, Georgia and Azerbaijan, Sweden. In 2017, Pope Francis visited Portugal, Colombia, Myanmar, Bangladesh, and Egypt. In 2018, he visited Chile and Peru, Switzerland, Ireland, Estonia, Latvia, and Lithuania. This year, up to June 2019, he visited Panama (23-27 January), United Arab Emirates (3-5 February), Morocco (30-31 March), Bulgaria and North Macedonia (5-6 May), and Romania (31 May-2 June).

During his leadership, through his speeches, letters, and apostolic writings, Pope Francis conveys his ideas not only on Christianity but also on global issues, such as on family, the environment, Mercy of God, peacebuilding, and others. He wrote his first apostolic exhortation on the fundamental mission of evangelization in the modern world (The Joy of the Gospel: Evangelii Gaudium, 2013a); he wrote an encyclical letter about the environmental issue which globally well appreciated (Praise be to You-Laudato Si: On Care for Our Common Home, 2015). On the issue of family and love, he wrote an Apostolic Exhortation (Amoris Laetitia On Love in the Family, 2016). His reflections about being Christian is also edited in his book Open Mind, Faithful Heart: Reflections on Following Jesus (2013). On many occasions, Pope Francis also stressed out several issues on the importance of collaborating with religions and countries to work for peace. He urged countries to end the war and work for the refugees and war victims. His voice is considered important in the political debate among nations. Up to now, in his six years of leadership when he is 86 years old, he is still active in public debates.

\section{Sheikh Ahmad Muhammad al-Tayyeb}

Ahmad Muhammad al-Tayyeb is a Grand Sheikh of the Al-Azhar University and Grand Imam of the Al-Azhar Mosque in Cairo, Egypt. He was elected in the time of Hosni Mobarak after the passing of Muhammad Sayyid Tantawi in 2010. 
Before being elected as a Grand Sheikh he was known for his role as a Grand Mufti in Egypt and a president of Al-Azhar University, one of the largest Sunni Islamic University in the world. He used to teach Islamic theology at International Islamic University in Pakistan, and in Aswan, Egypt. He also taught in several countries such as Saudi Arabia, Qatar, and the United Arab Emirates. As a Grand Sheikh of Al-Azhar, Sheikh al-Tayyeb is the central figure of Sunni Muslims in the world.

Playing his role as a Grand Sheikh of Al-Azhar University, Sheikh al-Tayyeb is known for his effort to keep the spirit of traditional Islam. The first years of his leadership were not as easy as after the political revolution in Egypt (2011 and 2013), the political sphere in Egypt was full of conflict. Moreover, the spread of terrorism endangered social cohesion in Egypt particularly. He tried to mediate the Egyptian government in the time of Mohammad Morsi. On many occasions, Sheikh al-Tayyeb showed that he is strongly against terrorism. He also responded to many social issues related to violence and terrorism. Moreover, he is known for protecting Al-Azhar University from the Muslim Brotherhood. He becomes an advocate of traditional Islam which takes the spirit of Islamic tradition (The Royal Islamic Strategic Studies Centre 2018:67).

$\mathrm{He}$ is active in dialogues among religious leaders in both interreligious dialogue and dialogue among Muslim leaders. He has a good friendship with Pope Francis. In Islamic organizations, he is active in the Supreme Council for Islamic Affairs, the Royal 'Ahl Ul-Bayt Academic
Institute for Islamic Thought. For his activities and scholarly works, he was awarded several medals and certificates, such as the First-Class Independence Medal from King Abdullah II of Jordan, Dubai Award of the Qur'an: The Islamic Personality of the Year Award, and he received the Honorary Doctorate from Maulana Malik Ibrahim State Islamic University in Indonesia, 2016.

Sheikh al-Tayyeb delivers his thoughts through his lectures, speeches, and writings. Among many of his writings, some are considered important: Mabāhith al-Illati wal Ma'lūl min Kitāb il-Mawāqif, Madkhal li Dirasat il-Mantīq il-Qadīm, Ta'liq 'alā Qism al-Ilāhiyyat min Kitābi Tahdhīb alKalām bi al-Taftazaniyy, and al-Jānib al-Naqdī fi Falsafat Abī al-Barakāt al-Baghdādi. His books on Islam and his speeches are translated into English and other languages, such as Essential Features of Islam (2017), and Speeches by the Grand Imam on Peace and Tolerance (2017b).

\section{Principle Ideas of the Role of Religion}

\section{Pope Francis's Ideas}

\section{Religion for Humanity}

During his leadership, Pope Francis clearly shows his concern on the role of Catholicism in public life. For him, faith should be expressed in public through service. Since his first encyclical letter Lumen Fidei (2013b) and the most importantly Apostolic Exhortation Evangelii Gaudium: The Joy of the Gospel (2013a), Pope Francis defines the fundamental task of being Christian in modern times is to spread the good news. He calls all Christians to share the joy of the Gospel to the world (Francis 2013a:1). Moreover, the profound 
joy of faith is understood as a light that should bring more light and joy to the faithful and society (Francis 2013b:4). The joy of faith does not being kept alone in silence, rather it is manifested in daily life (Francis 2013a:2, 2013b:4). Moreover, the Church, according to Pope Francis should "goes forth" to the social problems of the world. The Church, according to Pope Francis, is "supportive, standing by people at every step of the way" to better the world (Francis 2013a:24).

In those lines of thought, Pope Francis defines some contemporary challenges in which the Church should work. Humanity nowadays faces new social challenges, such as an economy of exclusion, idolatry of money, economy without ethics, and inequality which leads to violence (Francis 2013a:52-75). The mentality of competition puts the powerless and the poor to experience greater poverty. Moreover, the mentality of individuality also leads people into "globalization of indifference" where people lose concern and empathy toward others. Pope Francis also states that the challenges are not only in terms of mentality but also on the economic system which does not provide equal opportunity (Francis 2013a:43-54).

Looking at the criticism of Pope Francis, the importance of religion to play its role in the public sphere is obvious. Pope Francis quotes his predecessor Pope John Paul II who said that the Church should fight for justice (Francis 2013a:183). In the word of Pope Francis, the Church should be poor and for the poor (Francis 2013a:198). The Church cannot forget the poor. He also states that he begs the Lord to give more politicians who prefers to work for the poor. The poor are the homeless, the addicted, refugees, indigenous peoples, and the elderly (Francis 2013a:210). According to Pope Francis, "true power is service" (Morning Meditation in the Chapel of Domus Sanctae Marthae, 21 Mei 2013) (DiNardo 2016).

His criticisms and appeals are not only intended for Christians but for everyone. Religion in the hand of Pope Francis becomes a critic to the leaders and contemporary issues. The pope does not hesitate to criticize and appeal to politicians and world leaders. He strongly urged the European leaders and every country to welcome the refugees. In his speech to the United Nations in the United States, Pope Francis urged the nations to make a concrete step to address the issues of environment, economic exclusion, and migration (2015). Moreover, he urged all nations to end the war. In conclusion, he urged government leaders to guarantee human dignity through material and spiritual means.

With regard to the issues of collaboration, Pope Francis states that giving solution to the social problems is the task of religion and it should be done in cooperation with others. Religions, governments, and all people especially those in power have a responsibility to work for the common good. In his Evangelii Gaudium and Laudato $\mathrm{Si}$, Pope Francis urges government leaders, religious leaders, and everybody to work in collaborations. Pope Francis affirms that the Church opens to collaboration with all people and institutions to work together for humanity (238). Therefore, ecumenism, mutual enrichment, interreligious dialogue, and dialogue between believers and non-believers should be intentionally organized. In his Laudato Si, Pope Francis strongly denounces environmental damage caused by 
human greed (Francis 2015:48-52). Apart from that, the people most affected by environmental damage are the poor (Francis 2015:29-31). Therefore, it is the task of all to work together to save the world.

\section{Having Mercy and Forgiving}

Taking the episcopal motto, "Miserando atque eligendo" (by having mercy and by choosing him) taken from the call of Jesus to the tax collector in the Gospel of St. Matthew, Pope Francis put "mercy" at his center of his leadership. On March 13, 2013, Pope Francis declared a "Jubilee Year of Mercy" from December 8, 2015 to November 20, 2016. It was the time when the Catholic Church under Pope Francis's leadership offered the blessing and freed the Catholics who came to the Sacrament of Confession from their sins. Opening the year of mercy Pope Francis wrote apostolic letter "Misericordiae vultus" (Francis 2013c), and in the end the year Pope Francis wrote "Misericordia et misera" (Francis 2016b).

According to Pope Francis, mercy is the source of joy (Francis 2013c:2) where the salvation comes from. Mercy comes from God himself. It is, according to Pope Francis, the name of God. Pope Francis states that "being patient and merciful" as it is explicitly mentions in the Old Testament, are the identity of God. Therefore, through mercy people experience salvation from God. The manifestation of God is real in the act of receiving and giving forgiveness.

Therefore, the act of the faithful should be based on the spirit of forgiveness and mercy. Pope Francis writes:

How much I desire that the year to come will be steeped in mercy, so that we can go out to every man and woman, bringing the goodness and tenderness of God! May the balm of mercy reach everyone, both believers and those far away, as a sign that the Kingdom of God is already present in our midst! (Francis 2013c:5).

Pope Francis insists the faithful reach all people without borders. For him, the mercy of God should reach out to the sinners and those who are lost from God. Pope Francis disagrees to exclude or to condemn the sinners, but he believes that the faithful should bring joy to them so that they experience the forgiveness of God.

Looking at this thinking, for Pope Francis the faithful and religion must bring joy and hope to the world. In public, religion brings the merciful of God. Religion looks for the sinners and those who are lost to be forgiven. Religion does not exclude people but welcomes people from different backgrounds to experience the love of God.

\section{Sheikh Ahmad al-Tayyeb's Ideas}

\section{Differences and Dialogue}

On several occasions, Sheikh Ahmad alTayyeb emphasizes the important role of Islam and other religions to bring peace in the world today. Moreover, he believes that working for peace should be based on the spirit of religions itself. Therefore, in several of his writings and speeches, Sheikh al-Tayyeb cultivates the value of peace and dialogue from Islamic teachings and histories.

The most well-known meeting preceded the meeting of Sheikh Ahmad al-Tayyeb and Pope Francis in Abu Dhabi was a meeting in Cairo, April 2017, where both of them agreed on the role of religions for the work of peace-building. At the conference which was held during the visit of 
Pope Francis and was entitled "The Al-Azhar International Peace Conference" (27-28 April 2017), Sheikh al-Tayyeb stressed the coherence of the message of Muhammad and the message of Jesus, Moses, Abraham, and Noah on the moral principles (al-Tayyeb 2017c:308). Every religion has a common understanding of the content of moral principles and is different from others in practical guidance (al-Tayyeb 2017c:308).

Being rooted in faith, according to Sheikh, religions can get rid of differences and build common good for the world. Sheikh Ahmad alTayyeb mentioned that although religions stand in the similarity of faith, it consists of differences. Sheikh stated that the Holy Quran acknowledges the differences. The difference between religions, beliefs, languages, and colors is a will of God. The difference, according to Sheikh al-Tayyeb, "is the enactment of Allah with His servants, which will never be altered or changed until the world ultimately ceases to exist" (al-Tayyeb 2017c: 309).

Therefore, living in diversity, but sharing common values, people from every religion should build dialogue and acquaintance (alTayyeb 2017c:309-11). According to Sheikh alTayyeb, the dialogue is central in a diverse society that should be stood in the values of respect and good manners, while acquaintance is a fundamental requirement to build unity among differences. Sheikh al-Tayyeb showed that the Quran strongly put unity as its first principle which could be achieved through an acquaintance (al-Tayyeb 2017c:310).

Regarding Islam, differences and building harmony, in front of Muslim and Christian young people at the First International Forum for
Muslims and Christian Youth meeting in Cairo, August 2016, Sheikh al-Tayyeb strongly emphasized the need for dialogue and acquaintance. For him, Muslims will never hurt any human being. It is not allowed in Islam to harm people of other religions (al-Tayyeb 2017c:273). He puts his big hopes to the young people to build human fraternity and stop any violence and hatred in the society in the name of religion.

In his comprehensive work Muqawwimat ulIslam (Essential Features of Islam, 2017b). Sheikh Ahmad al-Tayyeb also puts Islam as a religion for all. In his explanation about Islamic legislation, Sheikh al-Tayyeb points out that Islamic laws should serve "the interests of all peoples, regardless of their nationalities, time and countries" (al-Tayyeb 2017b:245). He defines the role of Islamic legislation as resolving difficulties, caring for all people's needs and values, and working for justice for all (al-Tayyeb 2017b:24952). In his understanding, Islam does not serve Muslims only, but also all peoples and the world.

Moreover, Islam according to Sheikh alTayyeb, puts good manners as its moral principle. Islam as a religion cannot be separated from good manners. The daily life of Muslim is directed by good manners and in life is looking forward to achieving the perfect good manners. Sheikh alTayyeb quotes Sheikh Abdul-Kareem Zidan that "it is one of the highest objectives of Islam to perfect good manners" (al-Tayyeb 2017b:304). Therefore, doing something good for others is fundamental in Islam.

\section{Islam and Social Issues}

Sheikh Ahmad al-Tayyeb is also active in responding to social issues such as terrorism, misconceptions among religions, citizenship, and 
others. Many of his thoughts are systematically delivered in his statements, speeches at the conferences and meetings. His voices are not only delivered to Muslims but also all people from many different countries and religious backgrounds. His concern to put religion as an agent of social change and peace-building is obvious in his thoughts.

Living in Egypt and taking part in the Arab world, Sheikh Ahmad al-Tayyeb appealed to people of Egypt and the Arab world to work together for a common good. Moreover, during his leadership, Egypt faces miraculous social changes, namely the revolution in 2011 and 2013. In the revolution 2011, Sheikh Ahmad al-Tayyeb wrote a document entitled "Al-Azar Document on the Future of Egypt Endorsed by a Group of the Elite" (2011) where he urges people and nations in the Arab world to make a mutual dialogue for the sake of society renewal (al-Tayyeb 2017a:1729). He writes, "Al-Azhar called for a civilized dialogue between the Muslim nation and all other nations of the world to achieve the mutual benefit and supreme human interest" (al-Tayyeb 2017a:5-6). Sheikh al-Tayyeb claims that AlAzhar initiates dialogue among Egyptians, ArabArab, and Islamic-Islamic dialogue (al-Tayyeb 2017a:7). For him, dialogue for a common good for all is a message of the Quran, Sunnah, and Islamic practices.

After the January 25 revolution in 2011, Sheikh Ahmad al-Tayyeb also participated in a group of the elite in Egypt to discuss the future's Egypt. Sheikh al-Tayyeb agreed to support the government on several issues related to democratization in Egypt. There are eleven points. Some of them are to establish a constitutional, democratic and modern state, to have the direct election in a democratic system, to support human rights, pluralism, respecting religion and citizenship, to develop dialogue and mutual respect, to create international relations among nations, and to support education and research to find good solutions of social problems (al-Tayyeb 2017a:23-29). In recent times, Sheikh Ahmad alTayyeb is a supporter of the Egyptian government to combat radicalization and terrorism in Egypt.

The issues of freedom and citizenship also became the main concerns of Sheikh Ahmad alTayyeb's priority to the coming of Pope Francis to Egypt. Al-Azhar University and the Catholic Church hosted a conference entitled "Freedom and Citizenship: Diversity and Integration" (Feb 28-March 1 15t, 2017) where the Sheikh delivered a speech. Firstly, he felt painful to see war and killing in the name of religion. To respond to that issue, he suggested the need for practical guidelines and profound ethical principles based on religious teachings (al-Tayyeb 2017c:141). The Sheikh also underlined that citizenship is following Islam. Citizenship in Islam addresses equality and protecting all people. He insisted on the states to protect all citizens, freedom, properties, and human dignity (al-Tayyeb 2017c:159-61).

\section{Human Fraternity in Post-Secular Age: Synthetic Ideas of the Contemporary Role of Religion}

The meeting of Pope Francis and Sheikh Ahmad al-Tayyeb in Abu Dhabi, 3-5 February 2019 became a historic event where they reformulated the role of religion in a contem- 
porary society. During a Global Conference in Abu Dhabi, Pope Francis and Sheikh Ahmad al-Tayyeb signed a "Document on Human Fraternity for World Peace and Living Together" which in many ways is a culmination of their thoughts. Coming together as brothers, they agree on several issues such as the need for justice, working for the environment, helping the poor and marginal, religious freedom, and insisting that all nations work together on different social issues. Moreover, religions help their followers to have a good morality to support public discourse.

To understand the document, this writing borrows the theory of religion in a secular age of Habermas $(1983,1992,2008)$ particularly on the role of religion in public life. According to Habermas, religion is a source of morality. Religion urges its followers to have "meaning" in their life. Therefore, in his thought on pot-secular age, religion plays its role in public life to support the aspect of morality (Menoh 2015).

\section{Faith Seeks for Common Good}

The document is opened by a statement about faith that encourages the followers of religions to give respect to each other and doing something good for society, especially to "the poorest and those most in need" (Francis dan al-Tayyeb 2019:1). Although Catholicism and Islam mention differently about God, the document says that "the first and most important aim of religion is to believe in God, to honor Him and to invite all men and women to believe that this universe depends on a God who governs it" (Francis dan al-Tayyeb 2019:2). These views about God become a basis of this document so that the content of the document repeatedly says "In the name of God".
Pope Francis and Sheikh al-Tayyeb speak through the document as religious leaders, speaking in the name of God.

That point is already clear in the thoughts of Pope Francis and Sheikh Ahmad al-Tayyeb as explained above. As religious leaders, both of them understand that there is common ground to build brotherhood and to work together as brothers. Pope Francis always sees Muslims as brothers, while Sheikh al-Tayyeb mentions that people of different religious groups are brothers as well. Sheikh al-Tayyeb understands that the root of Catholicism and Islam is Allah of Abraham. Moreover, united as brothers there is no reason to live in hatred. Although this document stands in the name of God, faith itself does not only manifest in religious matters. Faith leads religious followers to do something good to others. Pope Francis and Sheikh al-Tayyeb repeatedly mention this point in their speeches and talks. In this line of thought, Habermas says that religions give a meaning for its followers which becomes practices in society. Religions urge their followers to do social actions in society.

Based on the statements of both religions leaders on the brotherhood of any religion, seen from the perspective of Habermas, there are no reasons for the adherents of any religion to be burnt in any violent conflict (Habermas 2006).

\section{Religions for the Needy}

Several paragraphs of this document begin with "In the name of". Sheikh Ahmad al-Tayyeb and Pope Francis call themselves representing "the innocent", "the poor" "the destitute", "the marginalized", "those most in need", "victims of wars, persecution, and injustice", "those who live 
in fear", "prisoners", "peoples who have lost their security, peace, and the possibility of living together", "orphans", "widows", "refugees", "those exiled from their homes and their countries", etc. It is interesting to note that for Sheikh al-Tayyeb and Pope Francis, religions do not represent themselves, but the people in need. Religions stand behind those who are weak and could not help themselves.

Therefore, through "Human Fraternity" Pope Francis and Sheikh al-Tayyeb want to bring religions into public life in the form of giving hope to those in need. Religions come to the public with a preference to help people. Religions do not become a private religion where its adherence practice personal piety, but religions help people. Moreover, religions do not represent themselves and their adherence only. Pope Francis and Sheikh al-Tayyeb mention that religion would help those in need. Religions have a responsibility to help all humans, not only their adherence. In this line of thought, religions serve all people. Religions are responsible for humanity.

In this context, the both leaders seek to formulate the religious activities that would be applied in social context to solve any problem in the contemporary world. Religious values existing in religion should be disseminated to make possible for people in general that the good values come from religion. The way they must implement the teaching also disseminated in religion language, to make sure that the teachings also coming from religion. Applying an appropriate medium, religious teaching will get all people well. For example, in the teaching of care to the needy, in Islam, it is stated in the al-Qur'an Surah al-Ma'un [107]: 1-7. In the social context, the care of the needy should be disseminated to people publicly to make possible for the people to be aware and careful of the people surrounding them. On another side, Christianity values also should be disseminated in such a way.

\section{Religions Seek for Peace, not Hatred}

Sheikh Ahmad al-Tayyeb and Pope Francis are aware of the danger of violence and hatred using religions. The document states that violence and hatred in the name of religions exist because of the manipulation of religious teachings. Fanaticism, extremism, and violence occur in many different places in the world because some groups and peoples incite hatred using religious terms. Some cases show that religion is misused by people in power to gain political and economic power. In this case, "Human Fraternity" insists to end the manipulations of religion. Pope Francis and Sheikh al-Tayyeb wrote:

We thus call upon all concerned to stop using religions to incite hatred, violence, extremism and blind fanaticism, and to refrain from using the name of God to justify acts of murder, exile, terrorism and oppression (Francis dan al-Tayyeb 2019).

In this line of thought, the document affirms to come to the essence of religious teaching that is peace. Religions should bring peace and harmonious coexistence; it should work for justice and love, and develop wisdom. It is important for Pope Francis and Sheikh al-Tayyeb to educate young people to develop the value of peace. New generations should be accompanied to grow in religious awareness and moral values. These concerns are also supported by the personal concerns of Pope Francis and Sheikh Ahmad alTayyeb in their leadership in the Catholic Church 
and Al-Azhar University. For young people should grow in faith and freedom.

\section{Dialogue and Collaboration}

Pope Francis and Sheikh al-Tayyeb call for dialogue and collaboration to make the world better. In the document they emphasize about the "culture of dialogue" and "cooperation". For them dialogue and collaboration are not only conducted among religions but also among nations. Moreover, they call religions, nations, and people of goodwill to collaborate and give positive contribution for society. Stressing about dialogue, they say in the document that:

Dialogue among believers means coming together in the vast space of spiritual, human and shared social values and, from here, transmitting the highest moral virtues that religions aim for. It also means avoiding unproductive discussions. (Francis dan al-Tayyeb 2019).

Furthermore, according to the two leaders that the task of religions in contemporary society is not only in spiritual matters, but also in addressing various social issues such as economic, social, political, and environmental problems. Moreover, for The Pop and The Sheikh religions must play role in making the contemporary world as a comfortable place for all people. This thought fits with Habermas' most recent argument that religion and secularization are interdependence (Habermas 1989, 2001).

\section{Conclusion}

Pope Francis and Sheikh Ahmad Muhammad al-Tayyeb are religious leaders who have important role in spreading the ideas of the important role of religion in solving contemporary problems.
Ahmad Muhammad al-Tayyeb is a Grand Sheikh of the Al-Azhar University and Grand Imam of the Al-Azhar Mosque in Cairo, Egypt. He was elected in the time of Hosni Mobarak after the passing of Muhammad Sayyid Tantawi in 2010. Before being elected as a Grand Sheikh he was known for his role as a Grand Mufti in Egypt and a president of Al-Azhar University, one of the largest Sunni Islamic University in the world. Meanwhile, Pope Francis from the Catholic Church was appointed as a pope in 2013. Coming from Latin America, as Archbishop of Buenos Aires, he moved to the Vatican and since that time has shown his concern in reforming the Catholic Church in terms of being a simple Church that works for the poor and plays its role in promoting world peace. His statement of "globalization of indifference" adresses thousands of illegal migrants who tried to reach Europe, many of them drowned in the sea, while many people and nations kept silent. This statement showed clearly his concern on contemporary problems.

In addressing various problems of the contemporary world, both religious leaders stated that conflict, terrorism, poverty, and the environmental crisis are among the problems that must be solved by the current global society. They introduced some religious ideas and perspectives to deal with the problems. Moreover, according to Pope Francis and Sheikh Ahmad Muhammad al-Tayyeb, the essence of religions is to bring peace and harmony to the world.

For the two leaders, solving the contemporary problem is not one religion's obligation and responsibility but all religions must cooperate and collaborate based on its basic values. Some strategies should be considered. Firstly, by 
teaching religious adherences and the world society about the fundamental values of religions. Secondly, by designing collaborative work among religions, nations. and all people in solving contemporary problems. Thirdly, by promoting and supporting the culture of dialogue and collaborations. As emphasized by both religious leaders that all people must work together for a common project. Fourthly, by cultivating knowledge and attitude that religions promote and support freedom and harmony and against any hatred and violence. Fifthly, by calling the world to end the use of religions to gain political and economic power.]

\section{References}

Ammerman, Nancy T. 2014. "Finding Religion in Everyday Life." Sociology of Religion 75(2):189-207.

Casanova, José. 2009. "Religion, Politics and Gender Equality: Public Religions Revisited (Draft)." in A Debate on the Public Role of Religion and its Social and Gender Implications, Draft Working Document of United Nations Research Institute for Social Development. Geneva: INRISD.

DiNardo, Daniel. 2016. The Joy of Discipleship: Reflections from Pope Francis on Walking with Christ. Chicago Illinois: Loyola Press.

Francis, Pope. 2013a. "Apostolic Exhortation: The Joy of the Gospel, Evangelii Gaudium." in United States Conference of Catholic Bishops. Washington, DC.

Francis, Pope. 2013b. Encyclical Letter Lumen Fidei: Of the Supreme Pontiff Francis to the Bishops, Priests and Deacons, Consecrated Persons, and the Lay Faithful on Faith. Roma: Libreria Editrice Vaticana.
Francis, Pope. 2013c. Misericordiae Vultus: Bull of Indiction of the Extraordinary Jubilee of Mercy. Roma: Libreria Editrice Vaticana.

Francis, Pope. 2013d. Open Mind, Faithful Heart: Reflections on Following Jesus. edited by G. Larrazabal. New York: The Crossroad Publishing Company.

Francis, Pope. 2015. Praise Be to You-Laudato Si: On Care for Our Common Home. Indiana: Our Sunday Visitor Publishing.

Francis, Pope. 2016a. Amoris Laetitia on Love in the Family. Vatican: Our Sunday Visitor Publishing.

Francis, Pope. 2016b. "Apostolic Letter Misericordia et Misera (20 November 2016)." Www.Vatican.Va. Retrieved (http://www. vatican.va/content/francesco/en/apost_le tters/documents/papa-francesco-letteraap_20161120_misericordia-etmisera.html).

Francis, Pope and Sheikh Ahmad Muhammad alTayyeb. 2019. "Document on Human Fraternity for World Peace and Living Together."

Habermas, Jürgen. 1983. The Theory of Communicative Action. Boston: Beacon Press.

Habermas, Jürgen. 1989. The Structural Transformation of the Public Sphere: An Inquiry Into a Category of Bourgeois Society. Cambridge, MA: MIT Press.

Habermas, Jürgen. 1992. Postmetaphysical Thinking: Philosophical Essays. Cambridge, MA: MIT Press.

Habermas, Jürgen. 2001. The Liberating Power of Symbols, Philosophical Essays. Cambridge: Polity Press. 
Habermas, Jürgen. 2006. "Religion in the Public Sphere." European Journal of Philosophy 14(1):1-25.

Habermas, Jürgen. 2008. Between Naturalism and Religion: Philosophical Essays. Cambridge: Polity Press.

Kaiser, Robert Blair. 2014. Inside the Jesuits: How Pope Francis Is Changing the Church and the World. Maryland: Rowman \& Littlefield.

Menoh, Gusti A. B. 2015. Agama dalam Ruang Publik: Hubungan Antara Agama dan Negara dalam Masyarakat Postsekuler menurut Jurgen Habermas. Yogyakarta: Kanisius.

Sachs, Albie. 2012. "Liberty, Equality, Fraternity: Bringing Human Solidarity Back into the Rights Equation." Journal of Human Rights Practice 4(3):365-383.
al-Tayyeb, Ahmad Muhammad. 2017a. Al-Azhar's Declarations. Cairo: Al-Azhar Center for Translation.

al-Tayyeb, Ahmad Muhammad. 2017b. Essential Features of Islam. Cairo: Al-Azhar Center for Translation.

al-Tayyeb, Ahmad Muhammad. 2017c. Speeches by the Grand Imam on Peace and Tolerance. Cairo: Al-Azhar Center for Translation.

The Royal Islamic Strategic Studies Centre. 2018. The Royal Islamic Strategic Studies Centre. The Muslim 500: The World's 500 Most Influencial Muslims. Amman: The Hashemite Kingdom of Jordan. 